\title{
Correlations of status positions of courtroom discourse participants
}

\author{
Irina V. Palashevskaya - Victor V. Leontiev - Elena A. Kurchenkova - \\ Elizaveta D. Stepanova - Dmitri S. Bulanov
}

\section{DOI: 10.18355/XL.2017.10.03.04}

\begin{abstract}
The article focuses on the status characteristics of courtroom discourse participants, including institutional position of a person and its correlations with other positions in the courtroom communicative space, modality of communicative acts, and speech formula, which constitute the courtroom discourse. The social status of a person, being the fundamental concept in sociology (Weber 1978, Parsons 1949, Abrahamson 1969), sociolinguistics (Bernstein 1979, Guy 1982, Harms 1961, Schatzmann, Strauss 1972), has been analyzed in the present article from the point of view of pragmalinguistics (Solan 1993, Karasik 2002, Eades 2008, Wagner, Cheng 2011). The pragmalinguistic approach to the status of a person involved in court proceedings aims to reveal the situational characteristics of equality / inequality relations in courtroom, finding reflections in certain agent types and communicative trajectories in communicative space, speech act types and their combinations, norms of verbal and non-verbal behavior and rules of communication, constituting the discourse.

Key words: courtroom discourse, status-marked communication, speech etiquette conventions, speech acts modality, communicative role, acts of reaction to role performance, preventive acts, coordination (harmonization) acts, interactional discrimination
\end{abstract}

\section{Introduction}

Discourse as well as language use, verbal interaction and communication belong to the micro-level of the social order. As for power, dominance, equality and inequality, those substances belong to the macro-level of the social order. In the everyday life both levels form one unified whole (van Dijk, 2001: 354). The courtroom discourse seems to constitute such a unified whole.

From the position of the theory of social action (Goffman, 1974, Habermas, 1984) courtroom discourse is the organized interaction of certain persons in certain circumstances of co-presence. The condition of participating in courtroom discourse is the legally codified status. Without formal legal acknowledgement of his / her status, no subject can be a participant of courtroom discourse and exercise certain functions.

Status descriptions normalize the process of interactions in certain institutional environment. These characteristics let the discourse participants foresee the behavior of other participants and plan their own actions. The study of the status characteristics manifestation in courtroom speech activity shows up how interlocution is being constructed at any moment of time and what are the principles of the construction of communicative events and the internal organization of institutional life.

The present article pays a certain attention to the nationally-specific sociopragmatic phenomenon of linguistic (im)politeness (for reviewing various theories of (im)politeness see: Leont'ev, 2016).

National specificity of linguistic (im)politeness is manifested in the fact that both verbal and non-verbal behavior, being appropriate and polite in one culture, seems to be inappropriate, impolite or even rude for representatives of another culture. Linguistic (im)politeness proves to be one of the main objects of studying the courtroom discourse (Archer, 2011, Harris, 2011, Kurzon, 2001, Terkourafi, 2012, 
Tracy, 2008, 2011). A courtroom is called an arena of "reasonable hostility" (Tracy, 2008) as "prosecuting lawyers ... often attempt to appear incisive, tough, even aggressive" (Archer, 2011: 7-8).

\section{Status characteristics and correlations of status positions in courtroom discourse}

The status characteristics of the courtroom discourse participants are determined by following attributes: a) the institutional position and its correlations with the positions of other participants in the situation of communication (the judge, the accused, the public prosecutor, the counsel, the witness, the victim, the expert, etc.); b) the genre modality of speech acts (the parties apply for smth., the witness testifies, the judge passes a judgment of conviction or acquittal and proclaims the sentence, etc.); c) formula organization of the discourse (the stereotype speech constructions reflecting the norms of communicative behavior which are popular in this lingua-culture in certain epoch) (Palashevskaya, 2012: 310).

The base characteristic of institutional communication is the presence of the system of interdependent positions according to which all the discourse participants perform their functions. An institutional position specified by the rights and duties of a discourse participant determines the access to the types of speech acts in the institutional discourse situations and it implies the spectrum of communicative possibilities and limitations. Every discourse participant has to take into account the presence of other persons, and the choice of one person's actions usually depends on the possibilities of other persons' behavior. The possibilities and limitations for any participant of the discourse are regulated by the set of formal and informal agreements and by "the procedure of uttering certain words in certain circumstances". In situational fragments of institutional practice a person of a certain rank or position is the one from whom other participants of the communicative action expect the proper role performance.

The mental models of the proper participating in the discourse seem to be explicated already at the level of spatial organization of what is going on. The space of the courtroom attaches particular significance to the institutional relations. The localization of the discourse participants in the space of the courtroom stipulates the trajectories and modality of communicative contacts between them. Symbolically the determination of the communicative space is expressed both in the dividing the judicial zone by subzones and in the floor level of these subzones. The functions of the judge as an independent arbiter are symbolically expressed in the fact that his place is on the dais. The parties' will is addressed to each other through the judge according to triangle communicative trajectory. Such the positioning of the figures is the way to demonstrate the status and it implies the number of ceremonial gestures, the aggregate of rules of addressing the person of a certain institutional position. The courtroom ceremony is also expressed in stereotype speech formulas, which are definitely organized, clichéd and steady; they are reiterated again and again.

The ceremonial constituent of courtroom discourse reflects the external form of the behavior of all persons participating in the discourse. So, when the judges enter the courtroom, all those present in the courtroom shall stand up. All the participants in the judicial proceedings shall give evidence and make applications while standing. A deviation from this rule may be made only with the permission of the presiding justice. The participants in the judicial proceedings, as well as the other persons present in the courtroom, shall use the institutionally codified formulas to address the court as "Esteemed Court", and the judge as "Your Honour" (CriminalProcedural Code of the RF, art. 257: Rules of the Court Session). The ceremony itself dictates the scenario of a dialogue development. In courts one can see the certain ceremonial variety but it is usually set by norms or tradition imperatively imposed to be followed without saying. 
A ceremonial act plays the role of the message of confessing other person's status. The breach of these rules causes the negative reaction, as it can be related to the intentional lowering of the social status of a certain participant of a communicative event. From these positions the following part of the courtroom dialogue can be of certain interest:

Judge: Have you got any more questions, Mr. M-vich.

Counsel for the Defence: Yes, I have got.

Judge: Everybody stands up here, but you do not, Mr. M-vich.

Counsel for the Defence: Public Prosecutor shall not stand up.

Judge: She did.

Counsel for the Defence: She shall not. If she believes that she...

Judge: Why do you protect the rights of the Public Prosecutor?

Counsel for the Defence: Excuse me, but one must somehow educate.

Public Prosecutor: I needn't to be educated.

Counsel for the Defence: Well, shall you stand or not? You shall not. I shall not stand up. I am a professional defense counsel, I am a lawyer, unlike, I beg your pardon, of other participants of the trial. Well, Your Honor, in my opinion, I am speaking of evident facts.

Judge: Well. Sit down, please!

Counsel for the Defence: Do you agree with me?

Judge: Sit down!

Counsel for the Defence: Thank you!

Public Prosecutor: Your Honor, I must just mention one thing. Mr. Lawyer, Mr. Mvich, next time, when you object the judgment, you mustn't start with the Prosecutor. Start with the Court if you are addressed any remark.

Counsel for the Defence: I must answer Public Prosecutor's remark. The matter is that I have mentioned you because you may have accustomed to the fact that Public Prosecutors always rise. Your Honor, you can believe that Public Prosecutors ... excuse me, I have been a lawyer for 30 years, thank God, I can tell you ...

Judge: We are attentively listening to you.

Counsel for the Defence: ... Lawyers shall not stand up. You have. It's up to you. Never mind.

Judge: Well, we have already explained. Mr. M-vich, you can ask the witness questions.

(from the transcript of the court hearing on the case of O. Orlov).

The refusal of the lawyer to follow ceremonial conventions provokes finding out if this refusal is connected with the conscious lowering of the court status ("Everybody stand up here but you do not"). The possible deviations of the substantial formalities of the kind take place in full accordance with certain rules, the Postulates of Politeness, the observance of which allows not to go across the line after which the actions of a person are qualified as contempt of a court. These rules imply the explanation which gives a certain rational good reason to the refusal: "I don't stand up not because I don't respect you but because I am a lawyer, and a lawyer shall not address the court while standing". The explanation in such cases seems to be one of the additional components of the status-marked situation, and it serves the purpose to restore the rapport and maintain the status correlations. The analyzed part of the courtroom dialogue explicitly proves the idea of D. Archer that "lawyers are not doing impoliteness" (Archer, 2011: 13).

The status correlations of the positions of the participants of the discourse are already evident at the level of address form. The contact form of interaction is regulated by the set of formal and informal speech etiquette agreements forming the

XLinguae Journal, Volume 10 Issue 3, June 2017, ISSN 1337-8384 
special culture of the mutual address forms. Let's analyze the following example from the past:

Accused: Comrades Judges

Presiding Judge: We aren't comrades to you

Accused: And what way should I address you?

Presiding Judge: You must say "Citizen Judges"

Accused: I am not a criminal and I don't want to address the Court the same way as the criminals must address the authorities ...

At the end of the dialogue the accused began to address the Court and the Public Prosecutor: "the Honorable Court" and "the Honorable Public Prosecutor" (Konstanov, 2007: 110). The cited fragment illustrates the intentional breach of speech etiquette conventions in the genre format of the court session (at that time when arrestees, prisoners and defendants to address the representatives of the law enforcement authorities had to say only the word "citizen": "citizen judge", "citizen public prosecutor", but not "comrade judge" (public prosecutor). The court insists on the dialogue unequal in status. The accused, after unsuccessful attempts to create the parity context of cooperation, deliberately increases the distance by means of the address formulas which in 1975 (the instance dates from that time) were considered to be the intentional grate on ears. The dialogue above demonstrates the degree of significance of an address form when speaking to a person in social public situation. This significance is in the fact that being the symbolic denotation of the status position of a certain subject in communicative situation, the address form symbolizes both the attitude to him/her and the willingness of addressing him/her in the format set by the institutional culture. So, it dictates the choice of corresponding linguistic forms. The address form "citizen" in this historical context explicates the presumptive attitude determined only by the procedural status of a person accused of a crime, and thereafter, the lexeme seems to be the inducement to the prosecutorial bias of the proceeding.

The ceremonial side of the status positioning in courtroom discourse is one of the theme, willingly applied to in the cinema:

D. Kaffee: I'm not through with my examination. Sit down.

Jessep: Colonel.

D. Kaffee: What's that?

Jessep: I'd appreciate it if he addressed me as Colonel or Sir. I believe I've earned it.

Randolph: Defense counsel will address the witness as Colonel or Sir.

Jessep: I don't know what the hell kind of an outfit you're running here.

Randolph: And the witness will address this Court as Judge or Your Honor. I'm quite certain I've earned it. Take your seat, Colonel.

(from R. Reiner “A Few Good Men”, 1992)

The significance of a presentation aspect of status positioning allows speaking about the performance discourse characteristics (Schechner, 2003). In courtroom discourse, there exist some important points: how the interaction event occurs, how the discourse participants taking up certain positions perform their roles; how the role performance is perceived by them and the others. This possibility to view self-performance from the observer's position and the integration in perception of the other person arises through the distance between the subject and his action. The participant of a discourse, performing certain acts, emphasizes this performance in a communicative situation (I am a lawyer, and the lawyer should not stand up, I am a lawyer, I have to hold the opinion of a defendant; as he does not admit guilt, my opinion is the same: he is not guilty, etc.). Acts in which the demonstration effect is created by a discourse participant are distinguished. These are acts expressing the attitude and relation of a discourse participant to his role: acts of refusal from a role, statements of rejection, the public prosecutor's renunciation of the charge, the same as 
his changing the charge, acts of a demonstrative distancing from a role. As an example we will give a fragment from the speech of a lawyer, the Counsel for the Defence:

My situation as a lawyer of the defendant N. K. is very difficult and inconsistent. Let me tell you, that it wasn't easy for me as a person to get acquainted with the materials of this criminal case in detail and re-experience the full horror of what had happened, to be with you in the courtroom for 10 months already, to see you heart-broken. It is a severe psychological stress. But you'll have to understand me - I am a lawyer and I had no choice. I am related to the position of the defendant. The defendant has a right to choose, the lawyer doesn't have it. I protect not a crime; I assert the rights of my defendant. My task is to find all facts justifying (acquitting him) or mitigating the position of my defendant in this case... And I hope that you will understand me (from the transcript of the Supreme Court of North Ossetia hearing on N. A. Kulayev's case (61)).

The subject does not identify himself completely with the action; he performs it consciously for the others and highlights this distanced performance.

Acts are distinguished in which the demonstration effect is created by an observer not an actor. They are the acts of reaction to role performance of other participants in the courtroom proceedings (acts of objections of any one participant in the judicial proceedings against the actions of the presiding justice, acts of a recusation, petition and complaint against the actions or the lack of actions, and also remarks, explanations, etc.). For example, if a person acts contrary to his status opportunities, pretends to perform the role of another participant:

Judge: Is the charge brought against you clear?

Defendant: No, Your Honor. The essence of the charge brought against me is absolutely unclear to me ....... and I would ask to explain me these circumstances in order to understand at least what I am accused of.

Judge: You are accused of making slander, in other words of propagating obviously false information discrediting honor and dignity of the other person or hurting his reputation which is contained in a public statement ....

Counsel for the Defence: Your Honor, I am forced to declare objections to your actions. We're having an examination of a case on an adversarial principle.

Judge: Certainly.

Counsel for the Defence: Functions of the court are separated from the functions of the parties .... Charge is explained by the one who raises it. Your Honor, if you begin to explain the charge, you take the charge function upon yourself ... In that case it is necessary to suggest Mr. prosecutor to explain this circumstance ...

Judge: It is quite natural that the judicial accuser has been appointed for this purpose. Counsel for the Defence: I say, that you've begun, Your Honor, to explain.

Judge: I can only explain the article, I won't certainly explain anything more and I have no right to it. I am listening to the State Prosecution.

(from the transcript of the court hearing on O. Orlov's criminal case)

The condition of courtroom interaction is a clear division of functions among the subjects, prevention of interference in the competence of the other person. The subject who is obliged to behave in a certain way is opposed to the subject appropriating someone else's status (in this case the status of the accuser). The dialogue is interesting because it combines the acts of critical supervision (You begin to explain, you take the charge function upon yourself), and the acts of introspection (I can explain [I'm explaining] only the article ...), the participants of the discourse create the effect of demonstration of the role performance together.

The role of the observer can be performed by some abstract person, a generalized other person, society as a whole. The view of himself or of the other with the eyes of

XLinguae Journal, Volume 10 Issue 3, June 2017, ISSN 1337-8384 
the public allows removing a concrete situation out of the court room limits, making it public for general supervision and estimation from the position of the highest moral authority. The position of such observer can be introduced as rhetorical device:

Reputable court!

.... In the theory of evidence there exists a concept "addressee of evidence". The addressee of evidence for the parties of charge and defence is court. Arguments of the prosecutor and the attorney are turned to it, they seek to convince it of their correctness. And is there an addressee of evidence for the court? Yes, there is. And this addressee is huge because it is all society.

The sentence must be that way that after having got acquainted with it and having compared with case materials, each ordinary citizen, as they say, an average person - a representative of the society - could say that the sentence is not groundless, there were evidences of guilt of the convict. Of course, the average representative of the society endowed with common sense understands that the court directly perceived evidences and investigated them, therefore had the right to trust ones and to reject others, to form a final conclusion on the internal belief.

But under all conditions the evidences mustn't be ridiculous, charge incompatible, and a sentence - inconsistent, disproving itself owing to internal contradictions.

I'll try to be transformed into this average sane person, ask several questions on his behalf and receive answers on them convincing the addressee of evidence ....

Esteemed Court! I am convinced that the virtual emergence of a typical representative of the society in the current court session will not remain as only an oratorical reception. Grigory Pasko's case resounded through the world, became sign. The courtroom drama of the officer-journalist marked a present stage of the development of the country and told about the relations of the society and the state, a person and the power brighter and more convincing, than official twaddle about the protection of the rights and interests of a personality, an oath of fidelity of the heads of judicial system and security agencies to the right and justice.

I believe that the date when Grigory Pasko's case will become available in all the volume to everyone who will wish to get acquainted with it is not so far. And the common sense multiplied by an innate sense of justice will pronounce the sentences: justificatory - to the war reporter and accusatory - to the military tribunal for the conviction of the innocent (G. Reznik in defence of the war reporter G. Pasko, in Military board of the Supreme Court of the Russian Federation on June 25, 2002). Explanations exposing communication possibilities and recipient restrictions appropriate to his or her institutional position belong to an act type directed to the role of other.

Judge: The Court is clarifying your rights provided by the Criminal Code of the Russian Federation. You have the right ... You may not give deliberately false evidence or refuse to give evidence; At the same time I clarify that with the permission of the presiding justice you have the right to testify at any moment of the trial. In addition, the court explains to you, that in terms of Article 51 of the Constitution of the Russian Federation, you have the right not to testify against yourself, your spouse and other close relatives.

Preventive acts are means of warning about the consequences of actions committed or not committed by a person and thus affecting the development of the discourse.

- If you agree to testify you are warned that your testimony may be used as the proof in the criminal case, even if you subsequently renounce them;

- You are the victim in this criminal case. Giving testimony is your right. However, you may not give false testimony or refuse to testify, so the court warns you about 
your criminal liability under Articles 307 and 308 of the Criminal Code of the Russian Federation.

Interactive acts are aimed at recognition of the proper role performance:

- Do you know your rights?

- Yes, Your Honor;

- Defendant, as the fact that you have been warned about your criminal liability, please, acknowledge it in writing.

- I have signed, Your Honor!

A special group of statements constitute coordination (harmonization) acts:

Prosecutor: I suggest the following procedure for examination of evidences in the case: to question the victim, to examine the witnesses, to examine the written materials of the case, to interrogate the defendant.

The victim: I have no objections to the proposed order.

Counsel for the Defence: I am content with it.

Defendant: I do not mind.

These acts are aimed at collective reproduction of the order, specified by the procedural norms so as to build interaction here and now again, using communication resources and capabilities that are ascribed to each of the institutional position.

The above units are the types of statements that inform about the action, describe its past, present or future performance, but are also actions of performative manifestation of activity, the fact of participation in the discourse and impact on it.

The ability to influence others, to seek for desired actions of other participants in the court proceedings when performing own functions is a prerequisite for participation in the judicial discourse. The degree of influence is expressed in predetermination or openness of the response to different forms of motivations of the subject which are oriented to other subjects in specific situations of communication. In one case, the subject because of its responsibilities is associated with the need of performance of actions required from him or her and with rigidly predetermined response to the motivation of the other. Otherwise he or she is not bound by obligations to act and react in a certain manner.

Such possibilities are actualized only in conjunction of positions in a situation of institutional interaction. The links between institutional positions define the modality of discourse and determine the degree of freedom of actions and the response to them in institutional structures. The degree of freedom of the recipient varies from zero mark, matching the use of coercion in different situations, i.e., external influence on the behavior of a person for the purpose of unquestioned obedience to the will of the acting person, up to granting freedom of reactions to his or her acts.

The participants of a status marked communication are modeled by means of the categories of case grammar (Fillmore, 1977) and include a universal set of roles, which are provided by the repeating fragments of an institutional practice designated by the verbs "accuse", "convict", "justify", "appeal", "interrogate", "decide", etc. As applied to the situations of courtroom discourse based on the model of adverse parties, it is possible to identify: 1) an agent - the initiator of an action towards the other participants of the communication; 2) a counteragent - the person with whom an agent makes multidirectional actions; 3) a patient - the person undergoing, an animated object of a purposeful agents' activity; 4) a recipient - the person acquiring; 5) a respondent - a higher official whom the agent addresses; 6) a superagent - the participant of a situation, on behalf of and in accordance with whose will an agent performs this or that action in relation to a patient (recipient), a counteragent or respondent. On the freedom degree of action the main participants of

XLinguae Journal, Volume 10 Issue 3, June 2017, ISSN 1337-8384 
the status marked situation are arranged in a decreasing sequence: superagent respondent - agent (counteragent) - patient (recipient) (see also: Karasik, 2002: 144).

A patient is the only one of the highlighted positions which is deprived of will importance in the institutional discourse situation actualized by an agent. His role is passive and his will isn't essential to influence a situation. This role is provided by coercion situations. A person detained on the suspicion of committing a crime or put under arrest, subjected to a personal search, brought forcibly to the inquirer, the investigator or to the court, presented for an identification to the witness or to the suspect, the person in respect of whom proceedings are under way which involve taking a coercive measure of a medical nature is deprived of his will in the actualized situation.

In coercion situations a patient acts as a person undergoing irrespective of his consent, an object of other actors purposeful efforts. Coercion is negative by nature; it is directed to the limitation of rights and personal freedoms, restraint of personal liberty, unlike recovery and compensation actions. So, a justification speech act assumes the cancellation of accusatory formulas against a person and the relevant procedural acts adopted on the stage of a preliminary inquiry, and, thus, recovery of person's status preceding his criminal prosecution liability. As a rule, in communicative situations of authoritatively administrative influence (a resolution on taking the given person to the bar in the capacity of the defendant, pronouncement of the Judgement of Conviction) assuming a negative change of a person's status (accused - convicted), the patients' role is combined with the role of the recipient. This role in courtroom discourse assumes an acquisition of some opportunities in case of which usage the person acts as an agent.

Patients' role can be observed also in the situations of veiled or direct interactional discrimination, asymmetry of a real possibility to participate in courtroom interactions, influencing on discourse development. At different historical times Russian courtroom discourse reveals variable transitions from a rigid subject of power - object opposition to the interaction between the power and citizens, protected with the necessary rights, raising them to the status of subject. In the criminal court procedure a patient' role is an expected behavior pattern determined by an individual's status position in a particular situation. At the same time the same concrete situation can be comprehended differently by its participants, different semantic roles can be referred to the same positions. So, for example, the situation of accusation assumes the relations in which an accuser (agent) is opposed to an accused (counteragent), and the charge itself is a kind of challenge for adversary party to defend. At the same time a counteragents' role transforms into a patients' role in case of passivity of a person accused of a crime (if it is not a tactical move), when the accused acts as a "viewer" of the action deciding his destiny. To the contrary, a patient becomes an agent, for example, in the situation of filing appeals against illegal actions and decisions of the court and of the officials, conducting the criminal court proceedings, in situations of initiative address for consideration and the settlement of a certain procedural question at the forthcoming moment of a case progress. A person, whom the agent addresses to for protection and possibility of exercising his rights, acts as a respondent.

The feature of an adversary discourse consists in impossibility of the parties to influence each other directly and forcibly. Throughout the judicial process the parties address the Court (a respondent) with the petition for performance of the procedural actions or for passing the procedural decisions, which the court can satisfy or refuse to satisfy.

Speech acts of the judge as a holder of power are authoritative towards the parties, unlike the acts of the parties addressed to the judge. At the same time, all participants of a communicative situation act under the law, showing the legislator's will in their 
intentions (invisible superagent in the situations of courtroom discourse). The discourse participants obey not one another, but the law. From these positions requiring from the court a lawful decision, the party influences the court almost as imperatively, as the court influences the party. Hence, the protest against judge' actions which includes a categorical requirement (in dyad agent - counteragent) is the same natural form of legal judgment in which the party can inform court of its opinion, as a petition, i.e. a motivated agent's request to the respondent. However, requirements in courtroom discourse act as imperative speech acts in which the only possible action of the addressee is approved not owing to the speaker's status characteristics, his right to insist, but owing to arguments given to justify the requirement. The court makes this or that decision based on the legality and validity of the requirement of the party. Hence, the genre forms, differentiated by way of influence on an addressee, shouldn't assume some advantages for the public prosecutor who having made the decision to appeal against sentence, is entitled to file a presentation while the same defender's appeal is called a complaint.

Alternatively to patient, counteragent is a person, who interacts with agent. In this dyad the parties may perform competing actions, i.e. act as irreconcilably conflicting parties, but also actions aimed at finding solutions to converge, taking into account the mutual interests. The role of counteragent can be transformed into the role of coagent in reconciliation or agreement situations. Counteragent can act as an auxiliary agent or assistant and play an instrumental role. Here is an example of the formation of such a role transformation in a pair of a lawyer - a defendant through a "question-hint" in the following fragment of courtroom examination:

Presiding Judge: The evidences were recorded from your words, weren't they?

Defendant: The investigator was the initiator of my testimony.

Presiding Judge: Explain, please, how did your examination and record of testimony take place?

Defendant: This examination was constructed by putting affirmative questions by the investigator, and my answers to the investigator.

Presiding Judge: Are you tired of giving evidence?

Defendant: No, I feel not tired to testify.

Presiding Judge: How can you explain that the transcript of the interview shows that you stated events of the crime freely, and not by questions and answers?

Defendant: I can explain nothing on this.

Counsel for the Defence: Who recorded testimonies, given by you on the preliminary investigation?

Defendant: The investigator did.

\section{Conclusion}

It should be noted that these roles are not constant in the genre of interrogation. In one case, agent gets a "desirable" response to his or her question, by supporting the defending view point, in the other case - an "unwanted" response and then the role of the interviewee changes, he or she becomes a coagent paired with the opposite party.

This method of describing the semantics of communicative situations allows the participants to be considered in courtroom discourse as special types of modal relations, to reveal the selectivity of institutional interaction and the ability of role combinations (role-frames), the dominant roles and their transformation throughout the court proceeding, to determine the script types of communicative behavior in each specific case.

XLinguae Journal, Volume 10 Issue 3, June 2017, ISSN 1337-8384 


\section{Bibliographic references}

ABRAHAMSON, M. 1969. Social stratification // Abrahamson M. Sociology: An Introduction to Concepts, Methods and Data. New York: Van Nostrand Reinhold, pp. 156 -195. OCLC Number 7190.

ARCHER, D. 2011. Facework and (im)politeness across legal contexts: An introduction. In: Journal of Politeness Research. vol. 7, pp. 1-19. ISSN: 1612-5681.

BERNSTEIN, B. A. 1979. Social Class, language and socialization. In: Language and Social Context: Selected Readings. P. P. Giglioli (Ed.). Harmondsworth: Penguin, pp. 157 - 178. ISBN 0140802444 / 9780140802443.

BOCK, PH. K. 1968. Social Structure and Language Structure. In: Readings in the Sociology of Language. Joshua A. Fishman (Ed.) The Hague: Mouton Publishers, pp. 212 - 222. ISBN 90-279-1528-8.

DIJK, VAN T. 2001. Critical discourse analysis. In: The Handbook of Discourse Analysis. Schiffrin D., Tannen D., Hamilton H. (Eds.). Maiden (USA): Blackwell Publishers, pp. 352-371. ISBN: 0-631-20595-0.

EADES, D. 2008. Courtroom Talk and Neocolonial Control. New York: Mouton de Gruyter, 389 pp. ISBN: 9783110204827 / 9783110204834.

FILLMORE, C. J. 1977. The case for case reopened. In: Grammatical Relations. New York, San Francisco, London, Academic Press, Inc., pp. 59-81.

GOFFMAN, E. 1986. Frame Analysis: An Essay on the Organization of Experience. Northeastern University Press edition, Harper \& Row, 586 p. ISBN: 0-930350-91X.

GOFFMAN, E. 1972. Relations in Public: Microstudies of the Public Order. Harmondsworth: Penguin, 460 p. OCLC Number 799775534.

GUY, G. R. 1988. Language and social class. In: Linguistics: The Cambridge Survey. Frederick J. Newmeyer (Ed.). Vol. IV. Cambridge: Cambridge Univ. Press. pp. 37-64. ISBN: 0521308348.

HABERMAS, J. 1984. The Theory of Communicative Action. Vol. 1. London: Heinemann, 465 p. ISBN: 978-0-8070-1507-0.

HARMS, L. S. 1961. Listener judgments of status cues in speech. In: The Quarterly Journal of Speech. Vol. 47, n. 2, pp. $16-168$.

HARRIS, S. 2011. The limits of politeness re-visited: Courtroom discourse as a case in point. In: Discursive Approaches to Politeness. Linguistic Politeness Research Group (Eds.). Berlin, Boston: Mouton de Gruyter, pp. 85-108.

KARASIK, V. I. 2002. Language of Social Status. Moscow: “Gnosis”, 333 p. ISBN: 5-94244-008-5.

KOSTANOV, Y. A. 2007. Slovo i "delo" [Word and Case]: Selected works. Moscow: Verte, 352 p. ISBN: 978-5-903631-01-8.

KURZON, D. 2001. The Politeness of judges: American and English judicial behavior. In: Journal of Pragmatics. Vol. 33, pp. 61-85. ISSN: 0378-2166.

LEONT'EV, V.V. 2016. Lingvisticheskaya (ne)vezhlivost': k probleme soderzhaniya kategorii [Linguistic (im)politeness: to the problem of category content] In: Ehkologiya yazyka i kommunikativnaya praktika. № 1, pp. 70-83. ISBN: 2311-3499.

MEAD, G. H. 1934. Mind, Self and Society from the Standpoint of a Social Behaviour. Chicago: The University of Chicago Press, 400 p. OCLC Number 643228340.

PALASHEVSKAYA, I. V. 2012. Sudebnyi diskurs: funkcii, struktura, narrativnost [Courtroom Discourse: Functions, Structure, Narrative]. Volgograd: Paradigma Publ., 346 p. ISBN: 978-5-9036001-67-7.

PARSONS, T. 1949. The Structure of Social Action. Study in Social Theory with Special Reference to a Group of Recent European Writers. Glencoe: The Free Press, $817 \mathrm{p}$.

SCHECHNER, R. 2003. Performance Theory. London: Routledge, 407 p. ISBN: 0415900921 / 9780415900928. 
SOLAN, L. M. 1993. The Language of Judges (Language and legal discourse). Chicago: The University of Chicago Press, 225 p. ISBN: 022676.

TERKOURAFI, M. 2012. Politeness and pragmatics. In: The Cambridge Handbook of Pragmatics. Allan K., Jaszcsholt K. (Eds.). Cambridge: Cambridge University Press, pp. 617-637. ISBN: 9781107558670.

TRACY, K. A facework system of minimal politeness. In: Journal of Politeness Research. Vol. 7. 2011, pp. 123-145. ISSN: 1613-4877.

TRACY, K. 2008. "Reasonable hostility": Situation-appropriate face-attack. In: Journal of Politeness Research. Vol. 4, pp. 169-191. ISSN (Online) 1613-4877, ISSN: (Print) 1612-5681.

WAGNER, A. \& CHENG, L. 2011. Exploring Courtroom Discourse: The Language of Power and Control. Burlington (USA): Ashgate Publishing Company, 267 p. ISBN: 9781409497653.

WEBER, M. 1978. Economy and Society. An Outline of Interpretative Sociology. Guenther Roth, Wittich Claus (Eds.). Berkley: University of California Press. In 2 vol., 1470 p. ISBN: 0520035003.

\section{Sources}

Criminal Procedural Code of the Russian Federation. Available at: legislationline.org/documents/section/criminal-codes/country/7

Full Trial Transcripts of the Court Hearings on the Criminal Case initiated against the Chair of the Board of HRC Memorial Oleg Orlov. Available at: http://www.memo.ru/2010/09/24/2409101.htm

Trial Transcript of The North Ossetia's Supreme Court Hearing on the Criminal Case of Nurpashi Kulaev (61). Available at: http://pravdabeslana.ru/61-160206.htm

Trial Transcript of the Supreme Court of the Russian Federation on the Criminal Case of G. Pasko. Available at: http://2002.novayagazeta.ru/nomer/2002/50n/n50ns14.shtml

Words: 6091

Characters: 38761 (10 standard pages)

Associate Professor Irina Vladimirovna Palashevskaya

Doctor of Philological Sciences

Department of Foreign Language Communication

Volgograd State University

Prosp. Universitetsky, 100

400062 Volgograd, Russian Federation

irina_777@volsu.ru

Associate Professor Victor Vladimirovich Leontiev

Candidate of Philological Sciences

Department of Foreign Language Communication

Volgograd State University

Prosp. Universitetsky, 100

400062 Volgograd, Russian Federation

leontiev_vgu@volsu.ru

Associate Professor Elena Anatolievna Kurchenkova

Candidate of Philological Sciences

Department of Foreign Language Communication 
Volgograd State University

Prosp. Universitetsky, 100

400062 Volgograd, Russian Federation

kurlena@ volsu.ru

Senior lecturer Elizaveta Dmitrievna Stepanova

Candidate of Philological Sciences

Department of Foreign Language Communication

Volgograd State University

Prosp. Universitetsky, 100

400062 Volgograd, Russian Federation

elizavetastepanova85@volsu.ru

Senior lecturer Dmitri Sergeevich Bulanov

Department of Foreign Language Communication

Volgograd State University

Prosp. Universitetsky, 100

400062 Volgograd, Russian Federation

english@ volsu.ru 